\title{
HOE DOELTREFFEND IS DIE INTERNASIONALE VREDESMAGTE?
}

Wrn. F.H. Swart*

The question regarding the effectiveness of the United Nations Organisation and in particular the UN Peacekeeping force, is a rather difficult one to answer.

Writers differ in their opinions on the question yet, when one takes into account recurring Newspaper Headings such as: "UN keeps busy, but has nothing to show", "UN-world body with a pretty bad conscience" and "Behind the noise another UN" - it becomes increasingly doubtful whether the United Nations Organisation and in particular the ineffective Peace Keeping force of this organisation - still has a right to exist.

\section{Inleiding}

Internasionale verhoudings het 'n evolusionêre ontwikkeling deurloop en daor word aanvaar dat dit reeds voor Christus by die Grieke ontstaan het. In teenstelling met die Grieke, wat nooit 'n blywende eenheid volkome tussen state kon bewerkstellig het nie, word gevind dat die Romeine op heel besondere wyse in sowel teorie as praktuk daarin geslang het om 'n internasionale verhoudingsbeleid te laat posvat. Deur die jare het verskeie moondhede en organisasies ontstaan en by gebrek aan 'n internasionale organisasie, het die hanithawing van vrede dus grootliks by die state self beru's en die magsewewigsbeginsel het hier ' $n$ belangrike rol gespeel.

Die "Konsert van Europa" word in die agttiende eeu in die lewe geroep. Hierdie organisasie het ontstaan tussen state wie se leiers hulself beskou het as lede van 'n algemene samelewing. Hulle was ook bereid om in terme te kommunikeer wat vir almal dieselfde betekenis gehad het. Lowenthall sê: "That is not the case as experience has shown, between the industrially advanced democracies of today and the states under Communist rule.

Die "Konsert van Europa" het nie alle oorloë verhoed nie, maar het dit minder waarskunlik en minder vitgebreid gemaak. Lowenthall toon aan dat "An international order in this more modest sense then, would be a sustem of relations, rules and possibly institutions that would be calculated to limit the use of violence in international affairs ..."

Na die Gerste Wêreldoorlog is die Volkerebond in 1919 in die lewe geroep om die ideale van vrede en stabiliteit te bewerkstellig en ook om die anargistiese sisteem te vervang. Die WO sou viteindelik vit hierdie organisasie sy ontstaan hê, maar Weiss skruf dat "Observers generally agree that, in contrast with the United Nations, the staff of the
League of Nations (particularly in the early years) was far more neutral and sought to counterbalance pressures from their national governments."

Die Volkerebond kon nie daarin slang om die Tweede Wêreldoorlog te verhoed nie en na hierdie oorlog, op 24 Oktober 1945, word die WO amptelik in die lewe geroep. Die doel van die Organisasie is as volg gedefinieer:

"To maintain international peace and security;

To develop friendly relations among nations;

To co-operate internationally in solving international economic, social, cultural and humanitarian problems and promoting respect for human rights and fundamental freedoms;

To be a centre for harmonising the actions of nations in attaining these common ends."

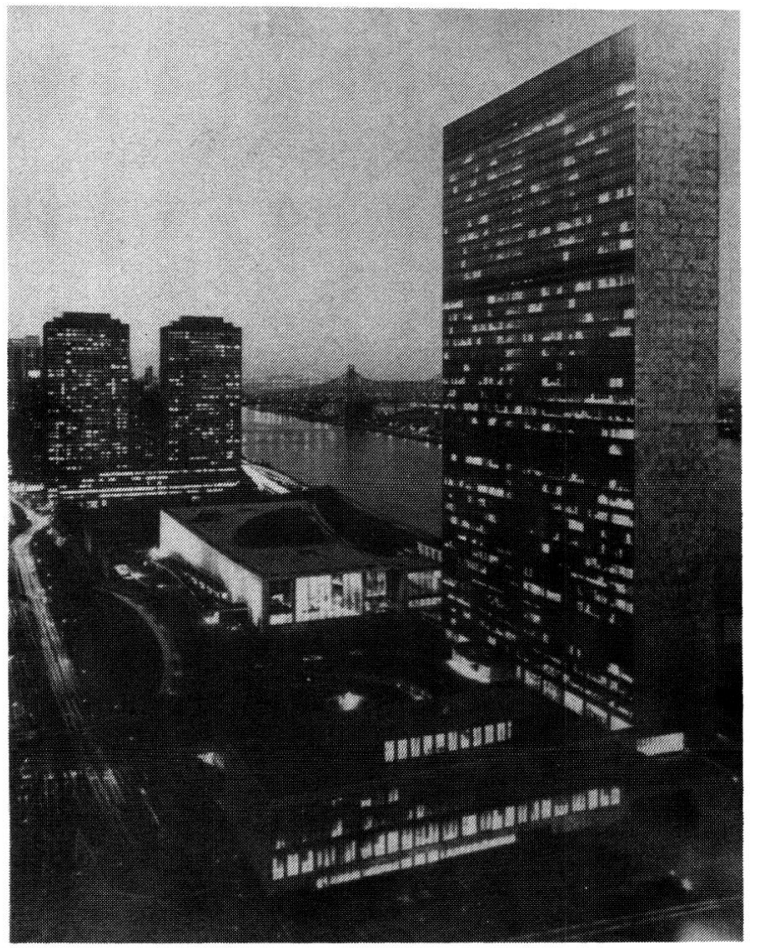

Die WO se hoofkwartler in New York (Foto: YOUR UNITED NATIONS - The Officlal Guldebook) 


\section{Iran}

Een van die eerste gevalle wat deur die WO behandel is, was 'n klagte van Iran in 1946 teen Russiese troepe wat die Azerbaijon streek steeds beset het en wat ingemeng het met Iran se interne sake deur die aanmoediging van 'n separatistiese beweging daar. Die verteenwoordiger van die USSR het die aanklag ontken, terwul die Raad besluit het dat die onderskeie regerings met onderhandelings moet voortgaon en die Raad op hoogte hou. In Moart daardie joar is die probleem weer bespreek en in Mei is dit laat vaor acngesien die Russe onttrek het.

Le Roụ Bennet sê dat hierdie geval 'n goeie illustrasie is van hoe die Sekuriteitsrand sekere geskille hanteer. Hụ sê onder andere dat "The Council is unable to use strong measures or coercion against a major power. The only weapon available is an appeal to Charter principles and to the good faith of the disputants, supported by publicity and world opinion". ${ }^{5}$ Hụ sê ook verder dat hulle nie juis veel meer kan doen as om die partue te nader om self tot ' $n$ oplossing te kom nie: "In the absence of contrary evidence, it may be reasonably assumed that in such cases settlement through negotiations was hastened by United Nations exposure and pressure."to

\section{Korea}

Die WO het die Korea-probleem in 1947 oorgeneem en het 'n vrye verkiesing voorgéstel, maor omdat die WO se warnemers nie toegelaat is om Noord-Korea te besoek nie, kon 'n verkiesing slegs in die Suidelike deel gehou word. Die Republiek van Korea het as 'n soewereine staat vit hierdie verkiesing ontwikkel. Die Noordelike helfte het teruggekap en hulself bekendgestel as 'n soewereine "Democratic People's Republic."

Gedurende die volgende twee jaar was daar heelwat militêre geskille aan beide konte van die "porallel." Op 25 Junie 1950 het die Weermag van Noord-Korea finaal aangeval en die Veiligheidsraad van die WO het dadelik reageer om 'n polisie-aksie te magtig. Hierdie magtiging is slegs moontlik gemaak deur die afwesigheid van 'n Sowjetverteenwoordiger bu die Veiligheidsraad. Die internasionale polisiemag het onder beheer van Amerika gestaan, terwyl die WO se vlag gebruik is. Vưftien lede, sonder die VSA en Korea, het aongebied om troepe te verskaf, naamlik Australië, België, Kanada, Columbia, Ethiopië, Frankrụk, Griekeland, Luxemburg, Nederland, Nieu-Seeland, die Fillipune, Thailand, Turkue, die Unie van Suid-Afrika en die Verenigde Koninkruk. Hierbenewens het 37 ander lede voorrade en dienste aangebied.

Stoessinger sê dat hierdie eksperiment met ' $n$ internasionale polisiemag nòg 'n sukses, nòg 'n fout was: "On the negative side, it owed its activation to a fortuitous circumstance- the Soviet Union's temporary absence from the Security Council ... on the other hand, the Korean experience broke precedent in several important ways. It saw sixteen nations fighting as a United Nations army, under the United Nations Flag and led by a United Nations commander." ${ }^{.7}$

Alhoewel die aggressor teruggedruf is, was Koreo nog steeds só polities verdeeld as tevore en ironies genoeg slegs 'n kort afstand van die "38th parallel" waar die gevegte begin het. Die WO se aksie het wel meegebring dot tud geskep is om die politieke geskille vit die weg te ruim, maor Stoessinger sê dat Korea se les duidelik spreek: "... that the pursuit of order through purely military techniques is bound to fail unless it is shored up by equally determined efforts to reach a political settlement." 8

\section{Cuprus}

Die Republiek van Cuprus het op 16 Augustus 1960 bu wuse van proklamasie tot stand gekom. Onenigheid tussen verdeelde faksies van Turkse en Griekse Cipriote lei in 1963 tot burgerlike konflik. Vertoë tot die WO om in te grup, lei tot die tussentydse daorstelling van ' $n$ tydelik vredesmag wat in 1964 vervang is deur ' $n$ sterk veelvolkige vredesmag, UNFICYP [United Nations forces in (yprus). Hierdie mag het tot in 1974, toe die Turkse inval plaasgevind het, hoofscaklik interne sekerheid en orde gehandhaaf. Hierna het dit 'n toesighoudende rol gespeel ten opsigte van 'n skietstaking en die skep van waarnemingsposte tussen die voorste elemente van die Turkse en plaoslike magte.

Oor die doeltreffendheid van hierdie ingruping word daar verskeie menings gehuldig. Alejandro $J$. Rodriguez Carrion meld die volgende in ' $n$ artikel getiteld, The United Nations force in Cuprus: An Uncertain Case of Peace-Keeping: "Prima facie, UNFICYP was an absolute failure: it did not accomplish its mission and, moreover, the situation ended up worse than it was in $1964 \ldots$ the failure of UNFICYP is more a failure of those countries engaged in the situation than one of the United Nations itself."

In sụ kommentaar merk die betrokke outeur op dat 'kollektiewe sekerheid' nie aan 'n vredesmag van 
die WO opgedra kan word nie, "but at present we must forget any approach intended to invest the United Nations, as such, with the right - and responsibility - for collective security."

In hul boek, The Thin Blue Line, wus Inder Jit Rikhye et al op die vredesmag se geïsoleerde suksesse te midde van sekere belemmeringe wat UNFICYP aan bande gelê het veral ten opsigte van troepebewegings: "UNFICYP was powerless to intervene. It would have been an act of enforcement had it done so." "In hierdie verband kon die vredesmag slegs die strudende partye se troepebewegings monitor en dit aan die WO rapporteer, maar kan geen voorkomende stappe neem nie. Brig Michoel Horbottle, Stafhoof van die vredesmag (1964-1968) merk dan ook tereg op: "As experience has shown, once fighting really begins, it is generally impossible for the United Nations to interpose a force."12 Waar die vredesmag soms deur tưdige optrede su militêre teenwoordigheid in 'n potensiële konflikgebied kon vestig, is kleiner skermutselinge wel voorkom of in die kiem gesmoor.

\section{Die Midde-Ooste}

In Oktober 1956 het die betrokkenheid van die WO by die Midde-Ooste 'n aanvän' geneem toe Israeli - magte die Sinai binnegedring het. Vertöë tot die WO lei tot die daarstelling van ' $n$ veelvolkige vredesmag, UNEF (United Nations Emergency Force in the Middle East), wat in 1957 in Gaza en Sharm el Sheikh stellings en poste vestig. Hierdie mag is onttrek kort voor die vitbreek van die oorlog in 1967 en sy rol is nog in dieselfde joar oorgeneem deur UNTSO (United Nations Organization Truce Supervision). Na die oorlog in Oktober 1973 het UNTSO bly voortbestaan hoewel twee bukomende magte geskep is, naomlik UNEF 2 en UNDOF

Oor die vredesmagte van die WO se effektiewe optrede, al dan nie, gedurende die tydperk 1956-1976 maak Yoel Arnon Tsur die stelling: "Experience has shown that the United Nations peace-keeping forces in the Middle East (and especially those established after the October 1973 War) have been effective in corruing out their mission (and I am not excluding the 1956 United Nations forces), but their position was and still is fragile and vulnerable to political hazards." 3 "Nöthling meld dat die grootste mislukkings egter die onvermoë van UNTSO in 1973 was om die oorlog can twee fronte (Sinai en Golan) te voorkom.

Betekenisvol is ook die feit dat hierdie vredesmag nie effektief kon optree ten opsigte van die vele skermutselinge wat sedert 1968 plaasgevind het nie. $^{14}$

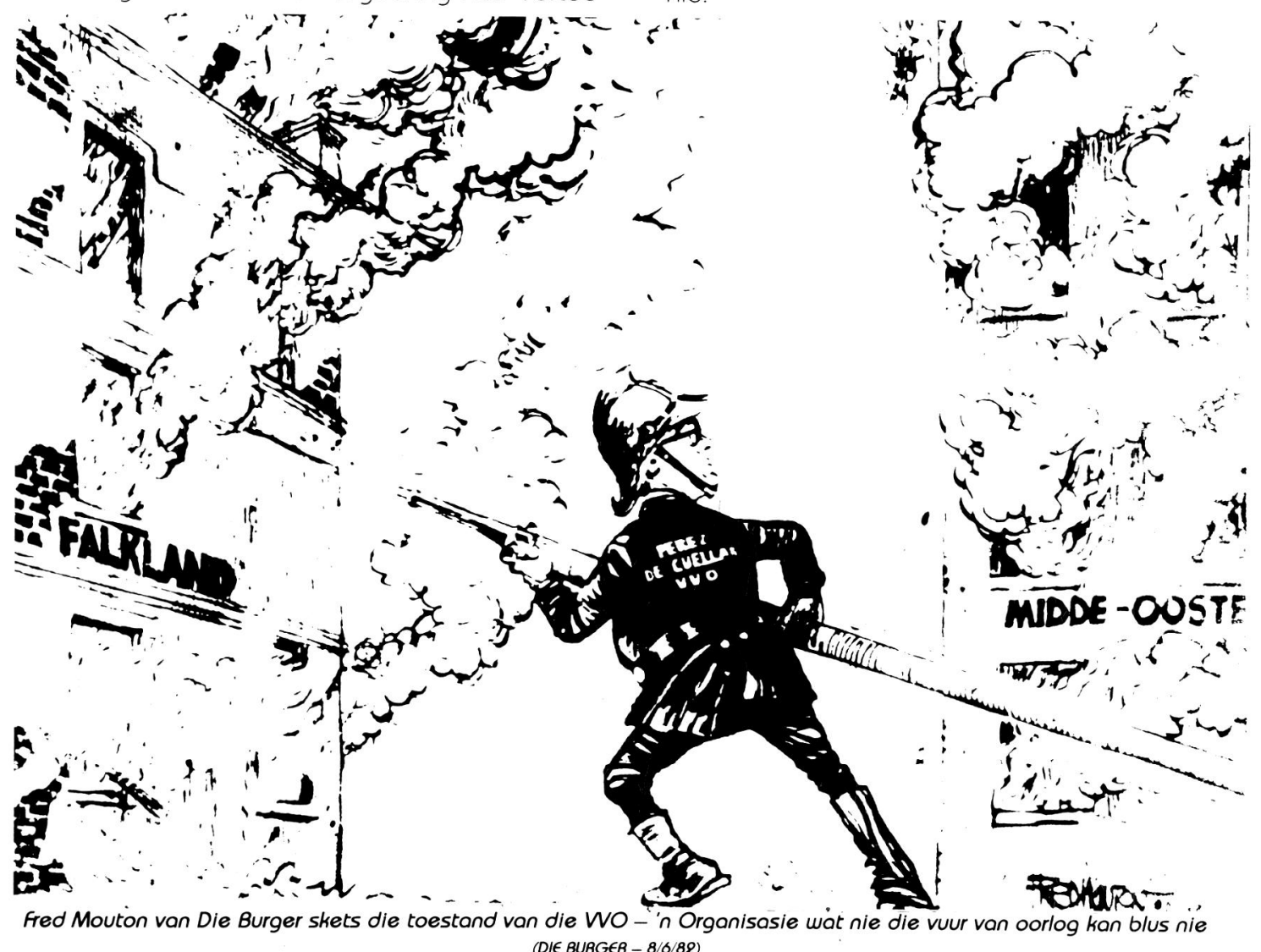


Tsur meld ook dat sodanige 'vredesoperasies' nie voorsiening maak vir die versoening van botsende belange wat die spanning tussen die strudende partue ten gronde lê nie: "According to this criticism, by the very fact of intervening to keep the peace, they also remove the sense of urgency from the problem and from attempts to find a lasting solution to it."15

\section{Kongo}

Op 30 Junie 1960 het die voormalige Belgiese Kongo (Zaïre) onafhanklik geword en enkele dae later is dié land in 'n bloedige burgeroorlog gedompel. Die interne situasie het verder versleg toe die Katanga-provinsie weggebreek het met 'n eensydige onafhanklikheidsverklaring en België begin om troepe na die Kongo te stuur. Vertoë deur die Eerste Minister, Potrice Lumumba, tot die WO om wet en orde te herstel het viteindelik gelei tot die stigting van 'n vredesmag, ONUC (Organisation des Nations Unies an Congo). Hierdie vredesmag was gedurende su verbluf in Zaire (1960-1964) betrokke in verskeie gevegte met rebelle en huursoldate.
Skruwers is dit eens dat ONUC in sy sending geslaag het hoewel dit by tụe op eie inisiatief en sonder die goedkeuring van die WO opgetree het. Rikhye et al skruf: "There is enough evidence to show that had the United Nations not intervened, the Congo would have become the cauldron into which other African States, the Soviet Union and other big powers would have been drawn on one side or the other, and the Congolese themselves would not have acquired the stability on which to build their independent nationstate."16

\section{Viëtnam}

Van effektiewe optrede van hierdie mag was daar min sprake en 'n skietstilstand is eers in 1973 met die vredesonderhandelinge in Parys bereik. In 1973 het die ICCS (International Commission for Central and Supervision) tot stand gekom, maar net soos sy voorganger, ICSC, was dit viters oneffektief. Hieroor het Rikhye et al hul soos volg vitgelaat: "The mechanism for controlling and supervising the ceasefire remains ineffective. The joint Military Commissions were and are unable to agree on anything of substance other than the exchange of the pris-

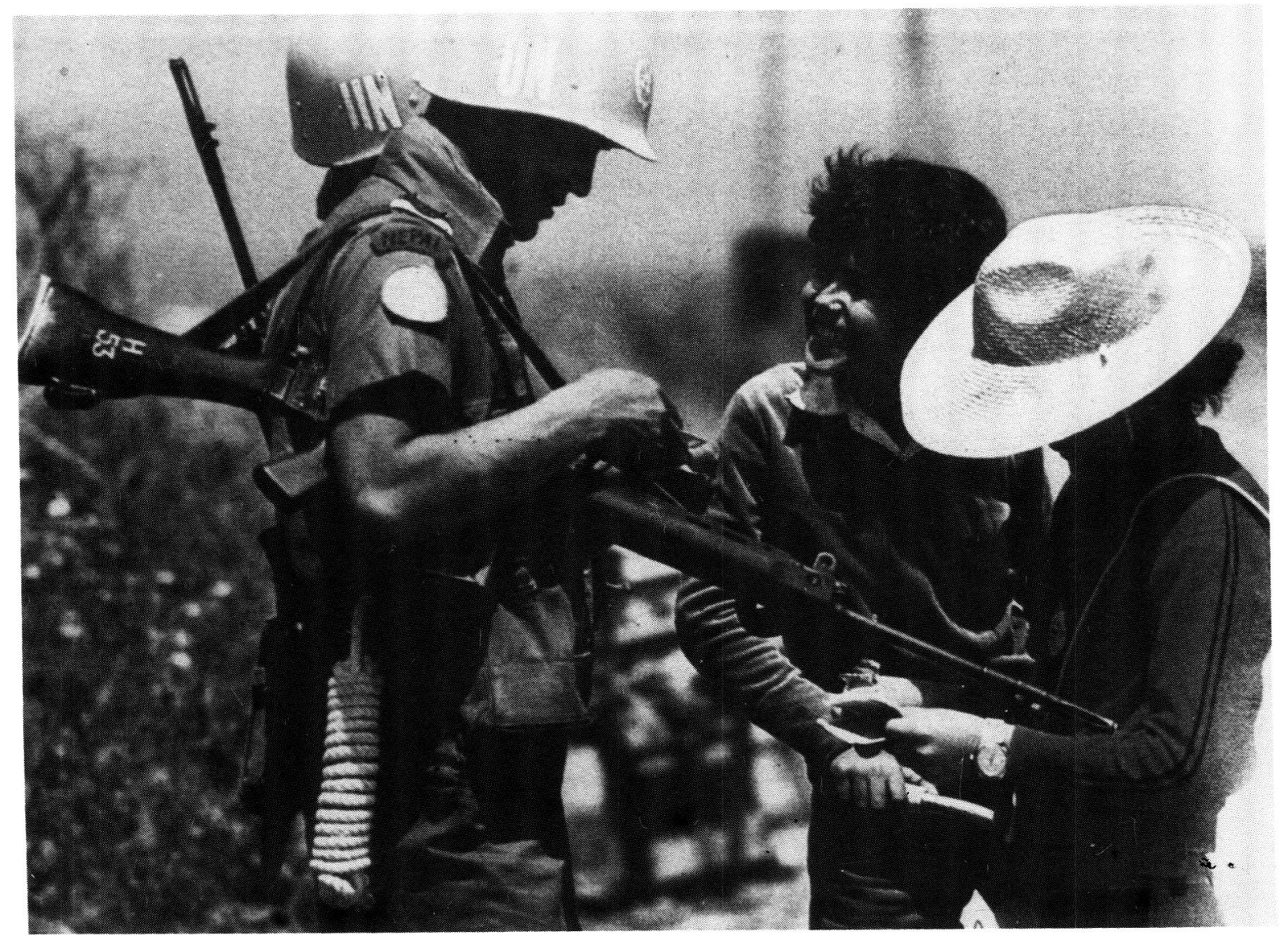

WO-vredesmagte, wat al vir langer as twee dekades in die Midde-Ooste geplaas is. (Foto: YOUR UNITED NATIONS - The Official Guidebook) 
oners of war ... Having no redress to a higher authority or headquarters, they were and remain powerless to influence the situation in Indochina."17

\section{Libanon}

Daar is tans ongeveer 90000 troepe van 16 lande sowel as die PLO (Palestine Liberation Organisation) besig met operasies in Libanon. In 1978 word 'n tussentudse vredesmag van die WO, UNFIL, in Libanon in werking gestel. Met troepe vit tien lande was UNFIL se doel "... to stop the Polestinians from attacking Israel, and the Israelis from invading Lebanon." 18

Vuf jaar later, in Oktober 1983, eindig die dienstudperk van UNIFIL en nog steeds kon daar nie 'n oplossing vir Libanon se probleme bevind word nie.

Daar word dringend aansoek gedoen vir ' $n$ verlenging van die dienstudperk en in sü verslag aon die raad sê die Sekretaris-Generaal van die WO, dr Javier Pérez de Cuellar: ". . . as die mag onttrek word voordat die Libanese regering gereed is om doeltreffende beheer oor die gebied vit te oefen, kan dit 'n ernstige terugslag vir die voorvitsig op die herstel van die gesag van die Libanese regering in Suid-libanon wees."

Intussen sterf soldate van Finland, Fidji, Frankruk, Ghana, lerland, Italië, Nederland, Noorweë, Senegal en Swede verniet vir die tussentudse vredesmag van die WO, want as daar nie sukses in die eerste vuff jaar behaal kon word nie, is die res vergeefs.

\section{Die MFO in die Sinai-Skiereiland}

Sedert 25 April 1982, die derde keer in die Geskiedenis, is ' $n$ internasionale vredesmag teenwoordig in die Sinai-Skiereiland. Anders as UNEF I en UNEF II, is die MFO (Multinational Force and Observers) se rol toesighoudend met die implementering van die vredesverdrag en opereer hulle nie onder die beskerming van die WO nie. As gevolg van die feit dat hierdie vredesmag gestig is buite die WO raamwerk, en afsonderlik die beginsels van volkereg nastreef, is hulle budrae tot internasionale vrede en veiligheid baie positief en effektief.

Majoor Cornelis Homan skruff in sy artikel, MFO. Peacekeeping in the Middle East, dat die MFO nou al 'n jaar besig is en volgens hom het die MFO baie

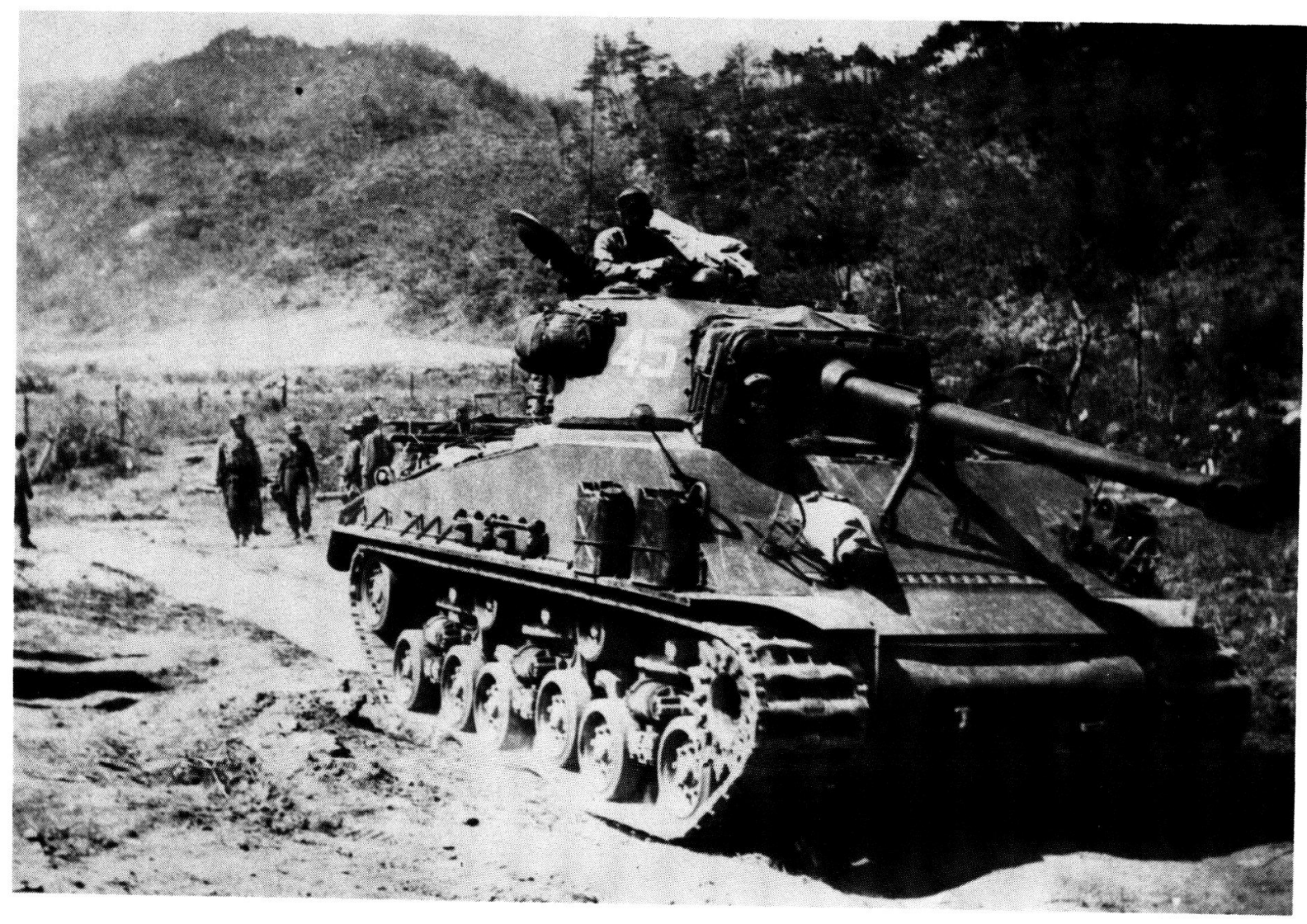

Gen van die WO se tenks in aksie. Is dit nie ironies dat'n vredesorganisasie met tenks te werk moet gaan nie? 
meer suksesse as die WO se UNEF I en II gehad. Hụ sê: "The most effective weapon of this force has been the collection of accurate and reliable information. Unlike many of the UN peacekeeping operations, the dissemination of this information is restricted to the parties of the treaty and the director general. This very critical procedure allows the parties to rectify violations and maintain open com- munication without the external pressure of media or other parties. Finally it appears that, in the absence of unanimity in the UN Security Council, a peacekeeping force, which is established outside the UN framework, but based on established principles of international law, can contribute positively to international peace and security." "20
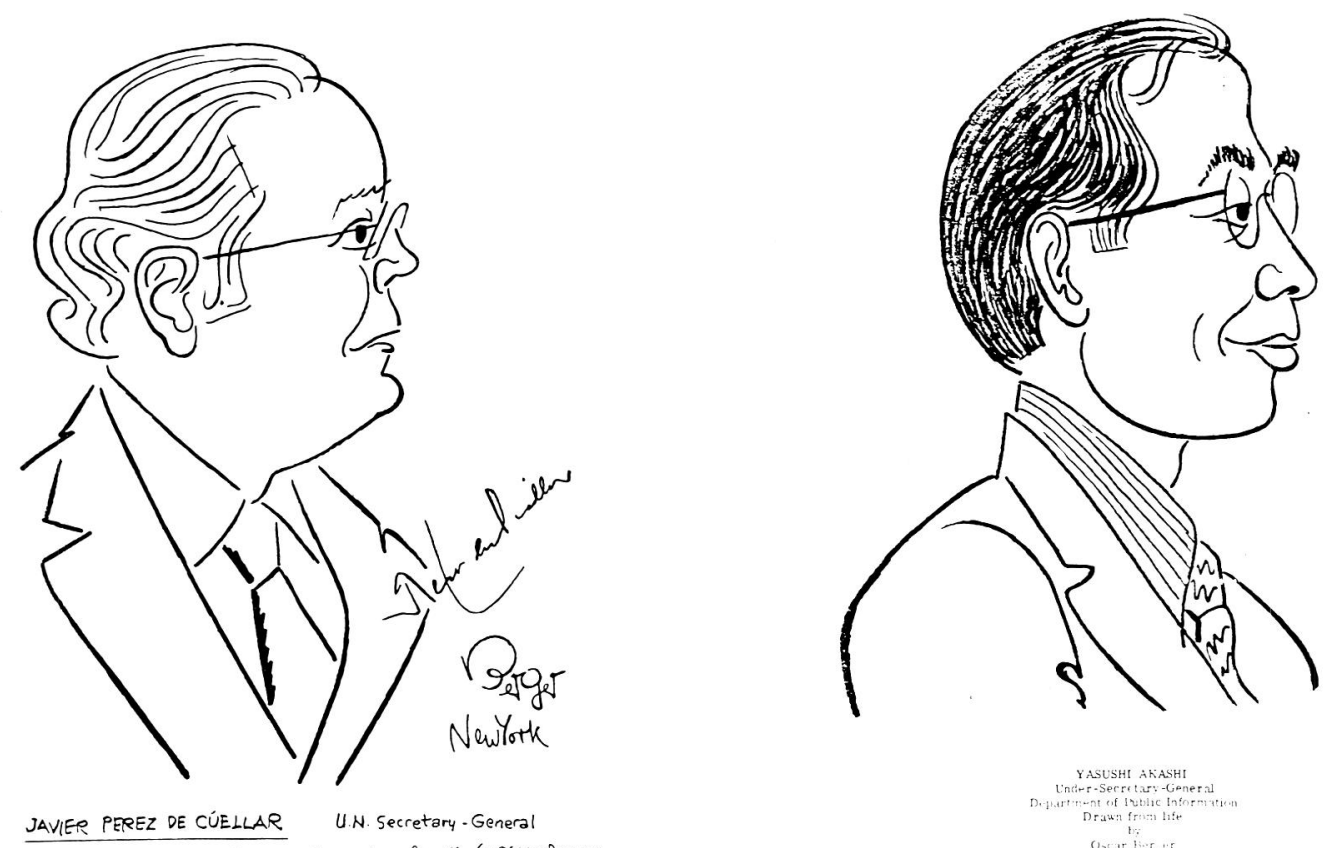

JAVIER PEREZ DE CÚELLAR U.N. Secretary-General

autograched suetch, drawn from life, Gy OSCAR BERGER

Die Sekretaris-Generaal van die WO, Die Onder-SekretarisGeneraal van die Departement van Openbare Inligting. Amerika se Ambassadeur by die WO en die President van die Algemene Vergodering

(Onderskeldelik geneem ult SECRATARIAT NEWS van 15/1/82, 15/4/83, 16/2/83 en 30/9/81.)
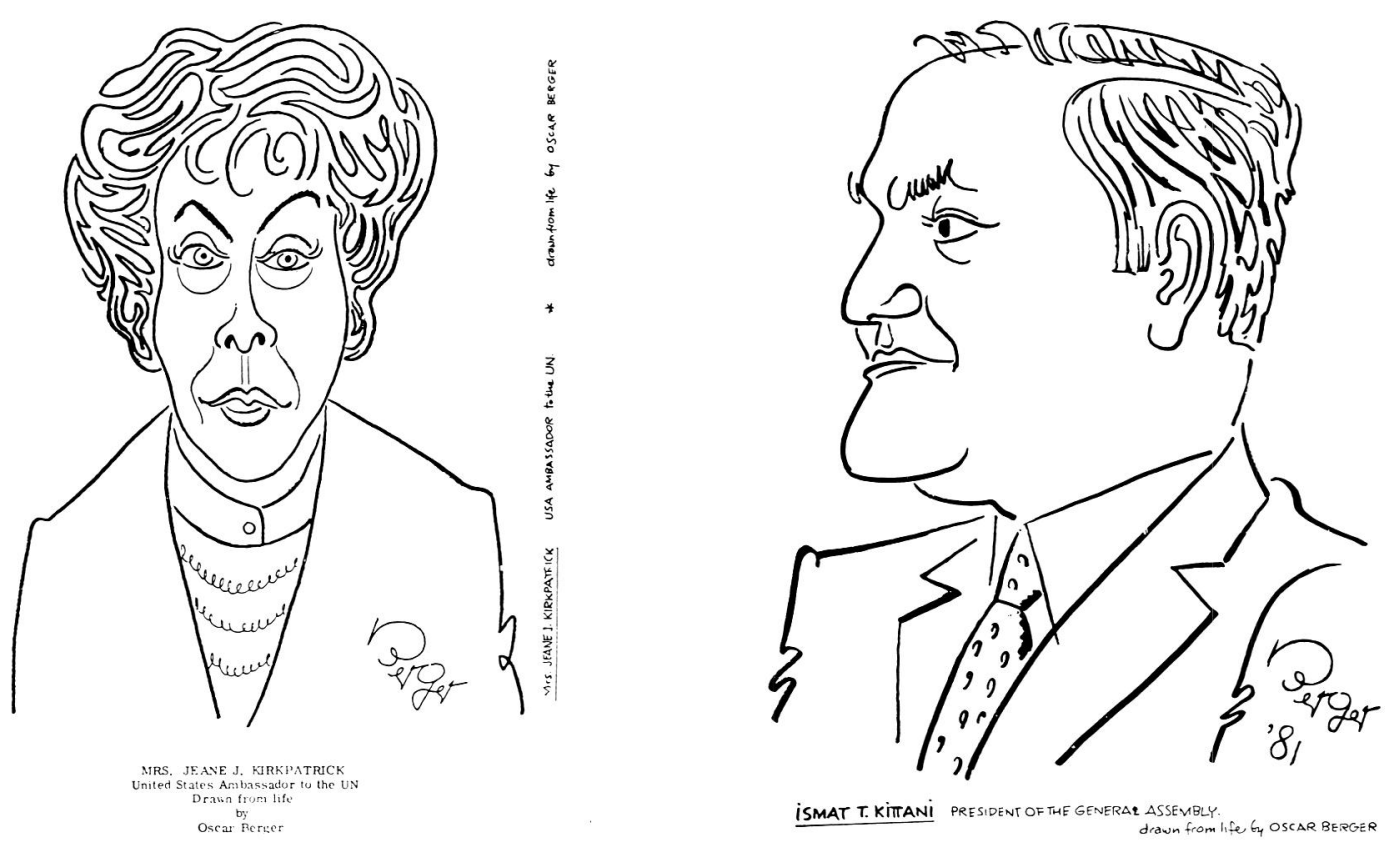

ISMAT T. KITAANI PRESIDENT OF THE GENERAR ASSEMBLYY. 


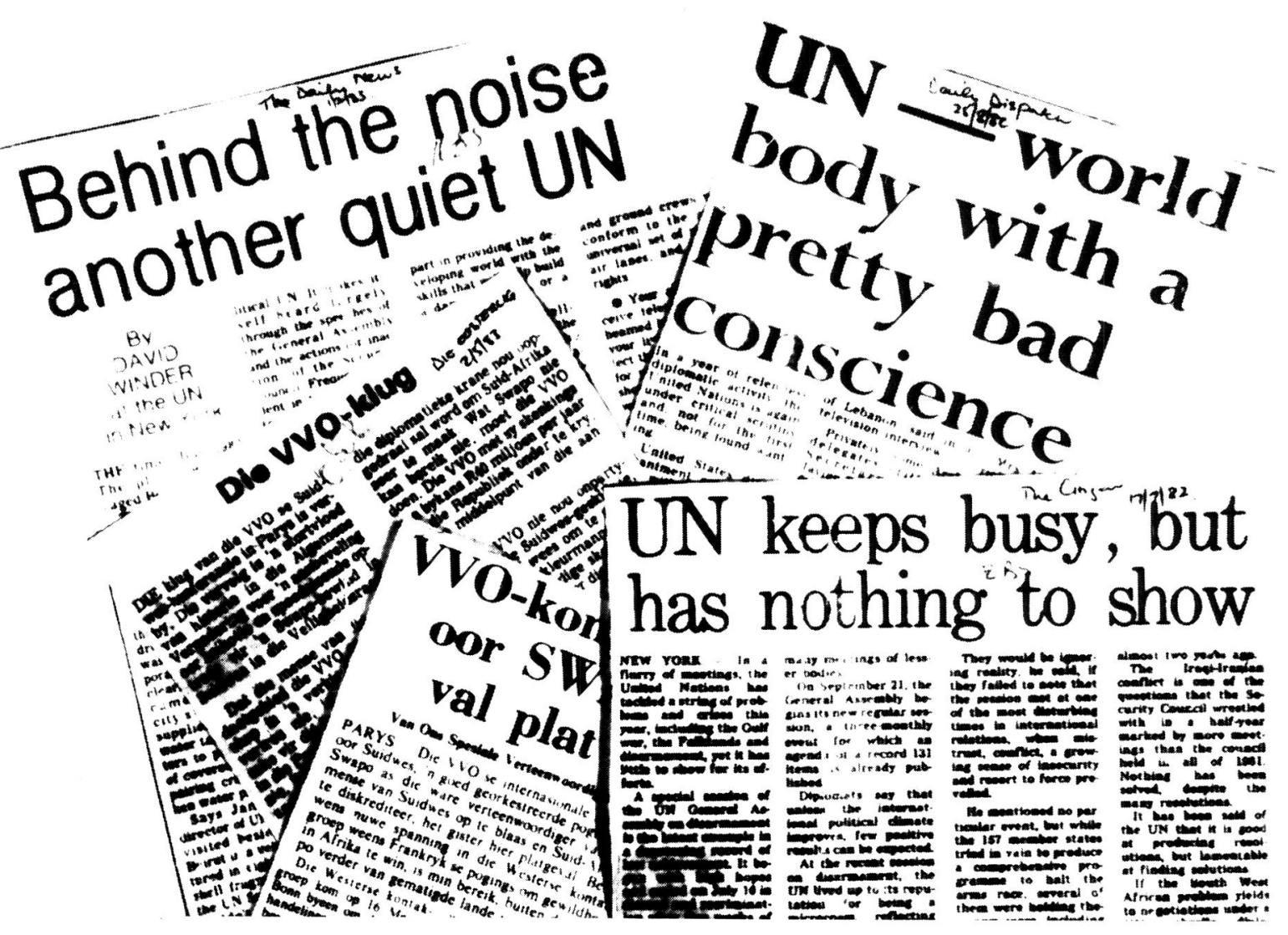

Koerante vertel die hele storie soos hierdie opskrifte aondui.

\section{Gevolgtrekking}

Die vraag of die WO effektief is al dan nie, kan moeilik beantwoord word ... altans nie in die be stek van een artikel nie. Uit die kort beskruwing hierbo van lande waorby die WO betrokke was of is, blụk dit duidelik dat die vredesmagte minder effektief was. Vergelụk die MFO se werksoamhede buvoorbeeld met die van die WO.

Verskeie skruwers huldig egter verskeie stondpunte oor die effektiwiteit van die WO. Le Rou Bennett glo dat die WO nóg bestoonsreg het, want "... the United Nations has shown its ability to adapt to limited crisis situations on an ad hoc bosis, and the utility of past operations provides encouragement for further efforts in this direction." 21

Mark W. Zacher toon harde feite aan: "While the United Nations intervened in 19 (20 percent) of the 93 conflicts, it only met with success in 8 of these. At the same time, in at least 5 others (the Indo-Pakistani war of 1947-48, the Arab-Isroeli wor of 1948, the Tunision-French war of 1961, the Moroccan Spanish conflict of 1975, and the South African involvement in the Angolan civil wor in 1975-76) its interventions did have some influence on the nature of the outcomes."22
Nöthling toon duidelik aon dat 'n WO-taakmag operasioneel nie effektief kan optree nie en hy gebruik Libanon as voorbeeld. Hụ dui ook aan dot die effektiewe optrede van 'n vredesmag verder belemmer word deur oorhoofse politieke besluite. "Soos verskillende outeurs contoon, sal die vredes mag nie slaag as dit nie die samewerking van al die betrokke (strydende) partye geniet nie. Dit het duidelik in Viëtnam oon die lig gekom. In su geskil met Libanon was Israel (soos in 1956 en 1967) nie geneë om met die vredesmag soam te werk nie."23

Stoessinger sluit hierby aan as hy sê: "But its task as crisis manager would be a great deal easier if nations submitted disputes before they went critical." Hụ wus ook daorop dat "... the most striking characteristics of the United Nations have been its elasticity and adaptability." ${ }^{4}$

Laves neem die WO se unieke karakter in oënskou en dui aan dat daar ontsettend baie hulp en steun van die WO verwag word - "... it is this unique character of United Nations assistance that gives hope that it may succeed where much bilateral assistance has failed and is probably bound to fail." 25 
Dit help egter nie om by vae teorieë te blỵ nie want bitter min suksesse is al met die sogenaomde riglụne behaal. Ledelande wil reaksie hê, wat hulle nie juis in die verlede ontvang het nie. TM Franck neem Afrika as voorbeeld as hu die situasie baie mooi opsom: "It is not surprising, therefore, that Africans should feel disenchanted with an organization of which they had come to expect so much and which seems to have accomplished so little in recent years." 26

Koerante is dit eens dat die WO nie suksesvol is of was nie. The Natal Mercury stel dit so: "Once more the United Nations - the organization which should be dousing the flames - is seen wallowing in its impotence." 27 The Citizen sê die volgende: "It has been said of the UN that it is good at producing resolutions, but lamentable at finding solutions."28 Die Daily Dispatch gaon nog verder: "Is the UN o haven for spies? Many Americans believe so and several UN employees from communist countries have over the years, been caught in the act." 29

Die Verenigde Volke Organisasie het deur moeilike jare gegaan en tog het die organisasie bly voortbestaon. Stoessinger het gesê: "What has not killed the United nations has made it stronger."30 Maar as 'n mens na koerantopskrifte soos "Die WO-klug, UN keeps busu, but has nothing to show, WO-kongres oor SWA val plat, UN-world body with a pretty bad conscience en Behind the noise another quiet UN" kuk, dan wonder jy of the WO nog enige bestaansreg het.

* Wrn F.H. Swart, BA (KOMMUNIKASIEKUNDE) (SA) is in Nosionale Dienspligtige verbonde aan die Militêre Informasieburo van die SAW.

\section{Voetnotas}

1. LOWENTHAL, Richard., The Diffusion of Power and the Control of Force in a New International Order., Adelohi Popers, No 134, 1977, o. 9.

2. Ibid, p. 9

3. WeisS, Thomas. G., International Bureaucracy: The Muth and the Realitu of the International Civil Service. International Affairs, Vol 58. No 2, Spring 1982, p. 303

4. LINDSAY-BROUNG, M., Peace-Keeping - How effective and at what price? The Armu Quarterly Defence Journal. Vol 1 12. No 2, April 1982. o. 166.

5. LE ROY BENNETT. A., International Organizations Principles and /ssues., Second Edition, London: Prentice-Hall International INc., 1980, p. 121.

6. Ibid, p. 121

7. STOESSINGER, John, G., The Might of Nations, New York: Random House Inc., 1979. Sixth Edition, p. 417

8. Ibid, p. 121

9. CASSESE, A., United Nations Peace-Keeping, Sijthoff \& Noordhoff, Alphen 1978, p. 176.

10. Ibid p. 121

11. INDAR IIT RIKHYY et ol, The Thin Blue Line, London/Ne Hoven: Yale University Press, 1974, p. 118

12. HARBOTLE, M., The Impartial Soldier, London: Oxford University Press. 1970, p. 193

13. CASSESE, oO cit, D. 211

14. NÖTHLING C.J., Die doeltreffendheid van Gedemilitariseerde sones in Cuprus, Viëtnam, Kongo, Lebanon ens., 12 Feb. 1982, o. 3

15. CASSESE, OO cit, 0. 211 .

16. INDAR JIT RIKHYE et al, op cit, p. 84

17. Ibid, op. 208-209.

18. The Citizen, Beirut-couldron of the Mid-East, 14 Moy 1983, p. 4

19. Beeld, Verleng Mandaar vra Pérez, 14 Okt. 1983, p. 10.

20. HOMAN, V., MFO: Peacekeeoing in the Middle East, Militarian Review, Sept. 83, p. 13

21. LE ROY BENNET, OP cit, p. 181

22. ZACHER, Mark. W.. International Conflicts and Collective Security 1946-77. New York: Praeger Publishers, 1977. p. 80

23. NÖTHUING op cit, p. 8.

24. STOESSINGER, OP cit, p. 347

25. LEPAUSKYY, A. et al (ed).. The Search for World Order, New York: Appleton-Century-Crofts, 1971, p. 350.

26. FRANCK, Thomos. M. Africo in the Un and the Un in Africa. New York Universitu, 1967, p. 20.

27. The Natal Mercury, Drifting Conflicts, 5 Aug 82, p. 14

28. The Citizen, Un keeps busy, but has nothing to show, $17 \mathrm{July} 1982.0$ 8

29. Daily Dispatch, UN - world body with a pretty bad conscience, 25 Aug. 1982, p. 16

30. STOESSINGER, op cit, $\rho .347$. 